\title{
Management Strategies and Innovations: Important Roles to Sustainable Construction
}

\author{
Bon-Gang Hwang ${ }^{1}$ and Ming Shan ${ }^{2, *}$ \\ 1 Department of Building, National University of Singapore, 4 Architecture Drive, Singapore 117566, \\ Singapore; bdghbg@nus.edu.sg \\ 2 School of Civil Engineering, Central South University, 68 South Shaoshan Road, Changsha 410075, China \\ * Correspondence: bdgshanming@163.com or bdgsm@nus.edu.sg; Tel.: +86-731-8265-5988
}

Received: 24 February 2018; Accepted: 25 February 2018; Published: 27 February 2018

\begin{abstract}
While sustainable construction has gained rapid growth worldwide in recent years, it is confronting various challenges and problems, particularly those from a management perspective. This Special Issue collects 16 original research articles relating to management strategies and innovations of sustainable construction, which are mainly concentrated in three areas: the adoption of sustainable construction technologies and products, the development of sustainable built environment, and the organization studies associated with sustainable construction.
\end{abstract}

Keywords: management strategies; innovation; sustainable construction

While sustainable construction has gained rapid growth worldwide in recent years, it is confronting various challenges and problems, particularly those from a management perspective. According to the existing literature, 30 percent of sustainable construction projects experienced rework [1]; 50 percent of sustainable construction projects were plagued by delay [2]; and 90 percent of sustainable construction projects required cost premiums to ensure project completion [3]. More than that, sustainable construction projects were also found to face diverse risks at a greater magnitude than conventional construction projects [4-6]. Such sad facts are sending a strong signal to authorities, industry practitioners and academics that careful, close, and particular attention should now be devoted to the management problems in sustainable construction projects.

This Special Issue collects 16 original research articles relating to management strategies and innovations of sustainable construction, which are mainly concentrated in three areas: the adoption of sustainable construction technologies and products, the development of sustainable built environment, and the organization studies associated with sustainable construction.

Five articles talked about the adoption of sustainable construction technologies and products. Chan, et al. [7] identified the important strategies that can promote green building technology (GBT) adoption in construction, and found "financial and further market-based incentives for GBTs adopters", "availability of better information on cost and benefits of GBTs", "mandatory governmental policies and regulations", and "green rating and labeling" were the top four important promotion strategies. Cho, et al. [8] analyzed the construction process and productivity of applying half-precast concrete slab system (HPCSS), a new type of slab systems. Cho, Shin and Kim [8] found that the construction productivity of HPCSS is 1.7 times that of a traditional slab system, and the cost per productivity unit of HPCSS exceeds that of a traditional slab system. Additionally, they found form crew and rebar crew were two critical resources affecting the HPCSS productivity. Xue, et al. [9] and Xue, et al. [10] explored the critical factors affecting the capital cost of prefabrication and found that "specification and standards for prefabricated building design", "related experience of manager", and "rationality of precast component split" were the most critical factors. Furthermore, Rochikashvili and Bongaerts [11] 
investigated potential solutions that can enhance end-users' awareness of environmental and health effects of the products they have purchased.

Four articles were focused on the development of sustainable built environment. Chun, et al. [12] developed an assessment model that can measure the social resilience of disaster management in 'resilient cities', a particular type of built environment constructed to avoid the occurrence of natural disasters. Using the former San Salvatore hospital in L'Aquila as an example, de Berardinis, et al. [13] illustrated how best-practice strategies can be implemented in the rehabilitation of an existing building. Mao, et al. [14] proposed a dynamic spatial-territorial reorganization model of rural settlement based on graph theory and genetic algorithm, with the intention of facilitating the decision-making of restructuring rural settlements in China. Liu and Chiu [15] investigated the deployment of creative industry in urban development and found that innovation capability, industrial cooperation, innovation incubation and industry-government-academia integration are crucial bases for cities to develop the creative industry. In addition, Liu and Chiu [15] highlighted that the policies of industrial $R \& D$ and clustering, talent training and industrial consulting and expanding industrial and marketing channels and networks can be adopted to enhance creative industry development.

Four articles look into the organization problems associated with sustainable construction. Park, et al. [16] investigated the causes of conflicts in energy projects in Korea, and found four types of causes: economic (e.g., decreased value of the land), construction-related (e.g., disturbance due to using the original route and site), and safety-related causes (e.g., concerns about explosions and accidents). Additionally, Park, Han, Lee and Lee [16] proposed a group of feasible strategies that can manage these critical conflicts. Jiang, et al. [17] investigated the influence of transformational leadership on employee performance in sustainable construction projects, and found that employee sustainable performance was positively influenced by transformational leadership and more than half of that influence was mediated by their organizational citizenship behavior. $\mathrm{Wu}$, et al. [18] developed a cooperative incentive model to investigate the cooperative relationship between owners and contractors in sustainable construction projects, as well as the synergistic effects created by cooperative behaviors. Mella and Pellicelli [19] investigated the levers that weaken people's intention of conducting sustainable behaviors. By doing so, Mella and Pellicelli [19] wish to find some panacea that can encourage people to conduct more sustainable behaviors.

In addition to the three areas above, risks and safety issues in sustainable construction projects were also covered. Hwang, Shan, Phua and Chi [5] conducted a systematic investigation of the risks in green residential building construction projects, and found that "complex procedures to obtain approvals", "overlooked high initial cost", "unclear requirements of owners", "employment constraint", and "lack of availability of green materials and equipment" were the top five critical risks in green residential building construction projects. Furthermore, Hwang, Shan, Phua and Chi [5] found that green residential building projects were facing risks at a more critical level than traditional residential building projects. Additionally, Hwang, Shan, Phua and Chi [5] proposed 14 mitigation measures to tackle the risks in green residential building construction projects. To address the safety issue and enhance safety at construction sites, Jo, et al. [20] presented a proximity warning system that can function in real time to alert workers and equipment operators of hazardous proximity situations.

Conflicts of Interest: The authors declare no conflict of interest.

\section{References}

1. Hwang, B.; Shan, M.; Tan, E. Investigating reworks in green building construction projects: Magnitude, influential factors, and solutions. Int. J. Environ. Res. 2016, 10, 499-510.

2. Hwang, B.-G.; Zhao, X.; Tan, L.L.G. Green building projects: Schedule performance, influential factors and solutions. Eng. Constr. Archit. Manag. 2015, 22, 327-346. [CrossRef]

3. Hwang, B.-G.; Zhu, L.; Wang, Y.; Cheong, X. Green Building Construction Projects in Singapore: Cost Premiums and Cost Performance. Proj. Manag. J. 2017, 48, 67-79. 
4. Hwang, B.G.; Zhao, X.; See, Y.L.; Zhong, Y. Addressing risks in green retrofit projects: The case of Singapore. Proj. Manag. J. 2015, 46, 76-89. [CrossRef]

5. Hwang, B.-G.; Shan, M.; Phua, H.; Chi, S. An exploratory analysis of risks in green residential building construction projects: The case of Singapore. Sustainability 2017, 9, 1116. [CrossRef]

6. Hwang, B.-G.; Shan, M.; Supa'at, N.N.B. Green commercial building projects in Singapore: Critical risk factors and mitigation measures. Sustain. Cities Soc. 2017, 30, 237-247. [CrossRef]

7. Chan, A.P.C.; Darko, A.; Ameyaw, E.E. Strategies for Promoting Green Building Technologies Adoption in the Construction Industry-An International Study. Sustainability 2017, 9, 969. [CrossRef]

8. Cho, K.; Shin, Y.-S.; Kim, T. Effects of Half-Precast Concrete Slab System on Construction Productivity. Sustainability 2017, 9, 1268. [CrossRef]

9. Xue, H.; Zhang, S.; Su, Y.; Wu, Z. Factors Affecting the Capital Cost of Prefabrication-A Case Study of China. Sustainability 2017, 9, 1512. [CrossRef]

10. Xue, H.; Zhang, S.; Su, Y.; Wu, Z. Capital Cost Optimization for Prefabrication: A Factor Analysis Evaluation Model. Sustainability 2018, 10, 159. [CrossRef]

11. Rochikashvili, M.; Bongaerts, C.J. How Eco-Labelling Influences Environmentally Conscious Consumption of Construction Products. Sustainability 2018, 10, 351. [CrossRef]

12. Chun, H.; Chi, S.; Hwang, B. A Spatial Disaster Assessment Model of Social Resilience Based on Geographically Weighted Regression. Sustainability 2017, 9, 2222. [CrossRef]

13. De Berardinis, P.; Rotilio, M.; Capannolo, L. Energy and Sustainable Strategies in the Renovation of Existing Buildings: An Italian Case Study. Sustainability 2017, 9, 1472. [CrossRef]

14. Mao, Y.; Liu, Y.; Wang, H.; Tang, W.; Kong, X. A Spatial-Territorial Reorganization Model of Rural Settlements Based on Graph Theory and Genetic Optimization. Sustainability 2017, 9, 1370. [CrossRef]

15. Liu, Y.-Y.; Chiu, Y.-H. Evaluation of the Policy of the Creative Industry for Urban Development. Sustainability 2017, 9, 1009. [CrossRef]

16. Park, C.; Han, S.; Lee, K.-W.; Lee, Y. Analyzing Drivers of Conflict in Energy Infrastructure Projects: Empirical Case Study of Natural Gas Pipeline Sectors. Sustainability 2017, 9, 2031. [CrossRef]

17. Jiang, W.; Zhao, X.; Ni, J. The Impact of Transformational Leadership on Employee Sustainable Performance: The Mediating Role of Organizational Citizenship Behavior. Sustainability 2017, 9, 1567. [CrossRef]

18. Wu, G.; Zuo, J.; Zhao, X. Incentive Model Based on Cooperative Relationship in Sustainable Construction Projects. Sustainability 2017, 9, 1191. [CrossRef]

19. Mella, P.; Pellicelli, M. How Myopia Archetypes Lead to Non-Sustainability. Sustainability 2018, $10,21$. [CrossRef]

20. Jo, B.-W.; Lee, Y.-S.; Kim, J.-H.; Kim, D.-K.; Choi, P.-H. Proximity Warning and Excavator Control System for Prevention of Collision Accidents. Sustainability 2017, 9, 1488. [CrossRef] 